\title{
Actions of GnRH antagonists on IGF-II, IGF-binding protein-2 and pregnancy-associated plasma protein-A in human granulosa-lutein cells
}

\author{
J M Weiss, B Krautmacher, S Polack, K Diedrich and O Ortmann \\ Department of Obstetrics and Gynecology, Medical University Lübeck, 23538 Lübeck, Germany \\ (Correspondence should be addressed to J M Weiss; Email: jmweiss1@hotmail.com)
}

\begin{abstract}
Objective: Recently, GnRH antagonists (GnRHants) have been introduced for the prevention of premature LH surges during controlled ovarian hyperstimulation $(\mathrm{COH})$. Here we investigated whether the GnRHants cetrorelix and ganirelix exert effects on the human ovarian IGF system. Since controversy exists on the action of GnRH agonists in the human ovary, we also tested the effect of triptorelin on IGF-II, IGF-binding protein-2 (IGFBP-2) and pregnancy-associated plasma protein-A (PAPP-A) in cultured human granulosa-lutein cells.

Design: In vitro cell culture study in a research laboratory of a university hospital.

Patients: Cells were obtained from patients treated with different protocols of $\mathrm{COH}$. In addition to gonadotropins they received triptorelin or cetrorelix. Cells were treated with triptorelin, cetrorelix or ganirelix, $1 \mathrm{nmol} / \mathrm{l}$ each, for $48 \mathrm{~h}$. IGF-II, IGFBP-2 and PAPP-A were measured by RIA and enzyme immunoassay respectively.

Results: GnRHants and triptorelin did not affect IGF-II, IGFBP-2 or PAPP-A.

Conclusions: We conclude that GnRHants do not exert any significant effects on the IGF system of granulosa-lutein cells and therefore their introduction into protocols of $\mathrm{COH}$ is unlikely to impair ovarian function.
\end{abstract}

European Journal of Endocrinology 149 31-37

\section{Introduction}

Gonadotropin-releasing hormone (GnRH) agonists (GnRHags) and more recently the GnRH antagonists (GnRHants) cetrorelix and ganirelix have been employed for several clinical indications like sex hormone-dependent diseases and infertility to suppress luteinizing hormone ( $\mathrm{LH}$ ) and follicle-stimulating hormone (FSH) secretion by gonadotropes (1). Before GnRHags suppress gonadotropins they induce an initial rise of gonadotropin secretion (flare-up), whereas GnRHants lead to a prompt inhibition of LH release by competitive binding to pituitary $\mathrm{GnRH}$ receptors. Apart from its pituitary actions, GnRH binds to specific receptors in numerous extrapituitary tissues $(2-7)$. After cloning of the GnRH receptor its gene expression has been demonstrated in the human ovary $(8-10)$. Brus et al. (11) indicated that high-affinity ovarian GnRH receptors are present predominantly in ovarian tissue after the LH surge. Minimal information is available on the actions of GnRHants in the human ovary (12). Recently we demonstrated that GnRHants exert no effects on ovarian steroidogenesis (13). Furthermore
GnRHants did not affect cAMP production in human granulosa-lutein cells (14).

GnRH analogs are currently used in different protocols of controlled ovarian hyperstimulation $(\mathrm{COH})$ for assisted reproduction techniques to prevent premature $\mathrm{LH}$ surges, which are detrimental for $\mathrm{COH}$ cycles (12, 15-19). GnRHants have been demonstrated to have a comparable clinical performance to GnRHags (16-18, 20). Recently, however, three large prospective randomized trials have compared GnRHants with GnRHags. Patients treated with GnRHants showed lower pregnancy rates. This difference was not statistically significant. But it was consistent in all three studies no matter whether cetrorelix was used in a single- (21) or multiple-dose (22) protocol or ganirelix (23) was used (24). Since GnRHants will be more widely used in protocols of $\mathrm{COH}$ in the near future it is important to further characterize their ovarian effects, which might be advantageous or detrimental for the treatment goal. Furthermore, such knowledge could enhance our understanding of the physiological role of $\mathrm{GnRH}$ in the human ovary. The lower pregnancy rates in GnRHants-treated patients with lower estradiol 
concentrations and lower implantation rates and the finding of $\mathrm{GnRH}$ receptors in human ovarian tissue prompted us to investigate whether GnRHants exert direct actions on human granulosa-lutein cells.

A debate arose whether GnRHants may affect growth factors responsible for folliculogenesis and mitosis, which itself is a prerequisite for human implantation. Growth factors, especially insulin-like growth factors (IGFs) are responsible for adequate folliculogenesis and embryonal development. An impairment of IGFs by GnRHants could explain a disturbed implantation (25). The predominant IGF in the human ovary is IGF-II $(26,27)$. The synthesis of IGF-II in the estrogen-dominant follicle increases dramatically at the time of follicle selection (28). It binds to IGF-binding proteins IGFBP-2 and IGFBP-4 (29). Recent studies noted that in dominant and luteinized follicles levels of IGFBP-4 were low. In contrast, high levels of pregnancy-associated plasma protein-A (PAPP-A), identified as a protease of IGFBP-4, were found (30). PAPP-A cooperates with IGF-II, whereas its binding proteins counteract its actions.

In the present paper we describe the actions of the two new GnRHants, ganirelix and cetrorelix, and the GnRHag triptorelin on IGF-II, its binding proteins IGFBP-2 and -4 and the protease of IGFBP-4, PAPP-A, as pivotal factors of the IGF system in human granulosa-lutein cells.

\section{Materials and methods}

\section{Protocols of $\mathrm{COH}$}

Human granulosa-lutein cells were obtained from patients undergoing in vitro fertilization/intracytoplasmic sperm injection. Two different stimulation protocols were used for $\mathrm{COH}$; these are the long protocol with a GnRHag and the multiple-dose GnRHant protocol. In the long protocol, patients $(n=25)$ received $3.75 \mathrm{mg}$ D-6-tryptophan-GnRH (triptorelin; Ferring, Kiel, Germany) s.c. 14 days before recombinant FSH application. Patients were treated with 2 ampoules (amps) of FSH (75IE) from day 2 of the cycle. On day 6 the dose of FSH was increased to 3 amps and thereafter the amount of FSH was adjusted according to the ovarian response. In the GnRHants group patients $(n=25)$ were treated with two amps of FSH from day 2 of the cycle. From day 7 the GnRHant cetrorelix (ASTA Medica, Frankfurt, Germany) was co-administered s.c. with FSH at a dose of $0.25 \mathrm{mg}$ per day as described previously (17). The dose of FSH was adapted to the ovarian response in the same way. When at least three follicles reached a diameter of $18-20 \mathrm{~mm}$ each ovulation was induced by administration of $10000 \mathrm{IU}$ human chorionic gonadotropin (hCG). Transvaginal ovarian puncture was performed $36 \mathrm{~h}$ later. The studies were been approved by the ethical committee of the Medical University of Lübeck.

\section{Granulosa-lutein cell preparation and culture conditions}

Follicular aspirates were obtained from patients treated with two different protocols of $\mathrm{COH}$ (see above). After collection of oocytes, aspirates were centrifuged at $175 \mathrm{~g}$ for $10 \mathrm{~min}$. The pellet was washed twice in PBS without $\mathrm{Ca}^{2+}$ and $\mathrm{Mg}^{2+}$. The cell pellet was resuspended in PBS, overlayed on Ficoll (Pharmacia, Uppsala, Sweden) and centrifuged at $300 \mathrm{~g}$ for $20 \mathrm{~min}$. Granulosa-lutein cells were aspirated from the interphase. After filtration to remove red blood cells, granulosa cells were resuspended in Ham's F10 medium containing $10 \%$ fetal calf serum, $100 \mathrm{IU} / \mathrm{ml}$ penicillin and $100 \mathrm{ng} / \mathrm{ml}$ streptomycin. Cells were cultured on multiwell dishes (200000 cells/well) in 5\% carbon dioxide, 95\% air and saturated humidity at $37^{\circ} \mathrm{C}$. Viability of the cells was always $>90 \%$ as demonstrated by trypan blue exclusion.

\section{Effects of in vivo treatments with GnRH analogs}

To test the hypothesis that long-term in vivo treatment with cetrorelix or triptorelin may affect the IGF system, granulosa-lutein cells from patients treated with the long agonistic protocol were compared with cells derived from patients to whom the antagonistic multiple-dose regimen was administered. Those cells experienced no in vitro treatment. Media were collected after $24 \mathrm{~h}$.

\section{Effects of in vitro treatments with GnRH analogs}

To exclude the possibility that fetal calf serum, which contain growth factors, may have an influence on the results of the experiments, incubation medium was replaced by medium which is free of serum and growth factors (Serum Replacement 2; Sigma, Steinheim, Germany). We employed different in vitro treatment protocols using GnRHags and GnRHants. Cells were exposed to $1 \mathrm{nmol} / \mathrm{l}$ triptorelin, cetrorelix or ganirelix for $48 \mathrm{~h}$. We used such a long culture period because the $\mathrm{COH}$ treatment of the patients includes high doses of exogenous gonadotropins, which might downregulate GnRH receptor expression (10). The prolonged culture period might be sufficient to allow recovery of GnRH receptors. We used the same concentration of $1 \mathrm{nmol} / \mathrm{l}$ for all $\mathrm{GnRH}$ analogs as we did in our previous studies (13), since this concentration was derived from studies on pharmacokinetics of GnRHants (31).

\section{IGF-II, IGFBP-2 and PAPP-A measurements}

IGF-II, IGFBP-2 and PAPP-A were measured in culture media. IGF-II was determined by RIA (Mediagnost, 
Reutlingen, Germany). Extraction of IGFBPs was performed by acid extraction. This method delivered consistent results. The sensitivity was $0.1 \mathrm{ng} / \mathrm{ml}$. Inter- and intra-assay variations were $<10 \%$. To test the consistency of the IGF-II assay we performed all experiments in triplicate. We obtained similar results in all sets, demonstrating that enough IGFBPs have been extracted by acidification. Therefore the binding proteins could not bind to IGF-II, which would interfere with results.

For IGFBP-2 measurement an RIA kit was used (DSL, Sinsheim, Germany). The sensitivity was $0.5 \mathrm{ng} / \mathrm{ml}$. Inter- and intra-assay variations were $<8.5 \%$.

No commercial RIA kit for IGFBP-4 was available. We designed one as follows: recombinant human IGFPB-4 and IGFBP-4 polyclonal anti-human antibody were obtained by R\&D systems (Wiesbaden, Germany). IGFBP-4 was iodinated. The second antibody used was anti-goat mouse serum. BSA at $0.25 \%$ in PBS buffer was used for the RIA.

Since no IGFBP-4 was detected by RIA we performed Western blot analysis using the same antibodies and recombinant human IGFBP-4.

In accord with recent studies by Conover et al. $(30,32)$ we were not able to detect IGFBP-4 in human granulosa-lutein cells, no matter which method was used.

Therefore we investigated PAPP-A, which acts as specific protease of IGFBP-4. Concentrations of the protein were determined by using an enzyme immunoassay (Biocat, Heidelberg, Germany). The intra- and interassay variations were below $5 \%$.

\section{Controls}

To test the sensitivity of all assays we tested different compounds serving as positive or negative controls as described in the literature. This would exclude the possibility that no differences between treatment groups is due to a lack of sensitivity of the assays. For IGF-II assay, cells were additionally treated with $70 \mathrm{ng} / \mathrm{ml} \mathrm{hCG}$ as a positive control. For IGFBP-2 assay cells were treated with IGF-II $(2 \mathrm{nmol} / \mathrm{ml})$ as negative and insulin $(1 \mu \mathrm{mol} / \mathrm{ml})$ as positive control.

\section{Data presentation and statistical analysis}

Each experiment was carried out with granulosalutein cells from one patient and was performed in triplicate. Data from 9-20 experiments were combined and presented as percent of basal release $(100 \%)$. Treatment groups were analyzed for statistically significant differences by the Mann-Whitney U-test or ANOVA followed by a Newman-Keuls test for comparison of individual groups, if more than two treatments were tested.

\section{Results}

\section{Effects of triptorelin, cetrorelix and ganirelix on IGF-II}

To test the sensitivity of IGF-II measurements we stimulated IGF-II release by hCG as a positive control; $70 \mathrm{ng} / \mathrm{ml}$ hCG could significantly enhance IGF-II secretion by $460 \%$ (data not shown). That is in the range described before (33). It showed that our assay is sensitive enough to detect even small stimulatory or inhibitory effects of the GnRH analogs on IGF-II. No differences in IGF-II levels could be demonstrated whether cells were from patients treated with cetrorelix compared with triptorelin. Cells received no in vitro treatment (Fig. 1).

Neither triptorelin, cetrorelix nor ganirelix in vitro treatment for $48 \mathrm{~h}$ was able to affect IGF-II secretion from granulosa-lutein cells. There were no differences between treatment groups (Fig. 2).

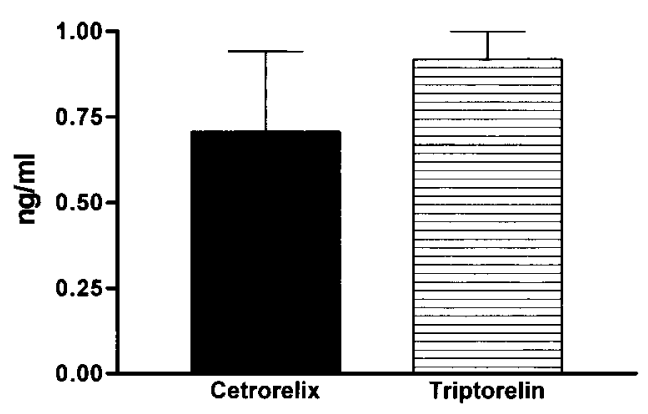

Figure 1 Granulosa-lutein cells from patients treated in vivo with triptorelin or cetrorelix were compared, 25 patients/group. Cells received no in vitro treatment. IGF-II was measured by RIA. Values are expressed as means \pm S.E.M.

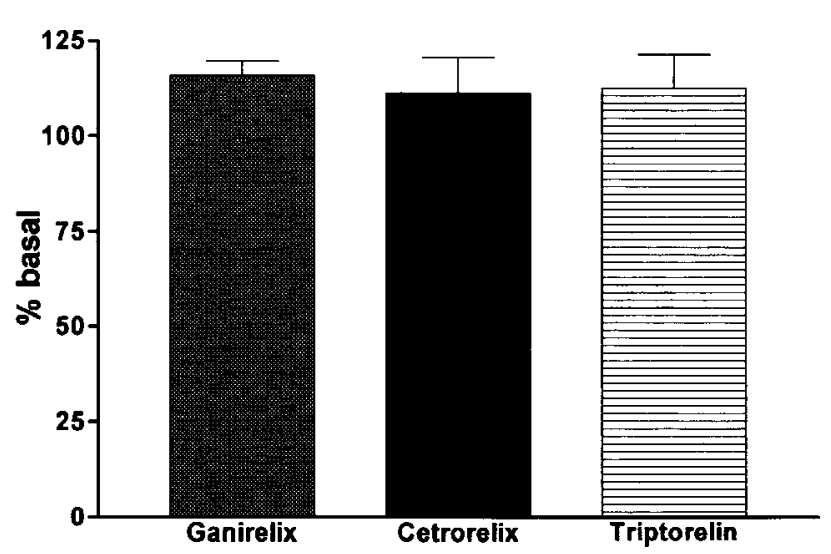

Figure 2 Granulosa-lutein cells were treated in vitro for $48 \mathrm{~h}$ with cetrorelix, ganirelix or triptorelin, $1 \mathrm{nmol} / \mathrm{l}$ each. IGF-II was measured by RIA. Untreated controls were set to $100 \%$. IGF values of different patients were in the range $0.47-1.1 \mathrm{ng} / \mathrm{ml}$. $5-10$ replicates were performed per group. Values are expressed as means \pm S.E.M. 


\section{Effects of triptorelin, cetrorelix and ganirelix on IGFBP-2}

We again tested the function of the assay used before experimental measurements. IGF-II as a negative control attenuated IGFBP-2 release to $90.3 \%$. On the contrary, insulin as positive control enhanced IGFBP2 to $112 \%$ (data not shown). IGFBP-2 concentrations did not differ in cells from patients treated with triptorelin or cetrorelix (Fig. 3).

No differences in IGFBP-2 secretion were found whether cells were treated in vitro for $48 \mathrm{~h}$ with $1 \mathrm{nmol} / \mathrm{l}$ triptorelin, cetrorelix or ganirelix (Fig. 4).

IGFBP-2 was not affected by GnRH analogs.

\section{Effects of triptorelin, cetrorelix and ganirelix on PAPP-A}

Since the detection of IGFBP-4 by different methods failed, we included the measurement of PAPP-A, the

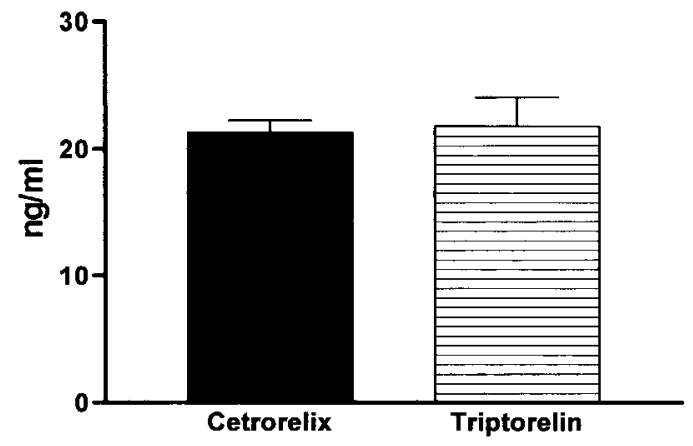

Figure 3 Granulosa-lutein cells from patients treated in vivo with triptorelin or cetrorelix were compared, 25 patients/group. Cells received no in vitro treatment. IGFBP-1 was measured by RIA. Values are expressed as means \pm S.E.M.

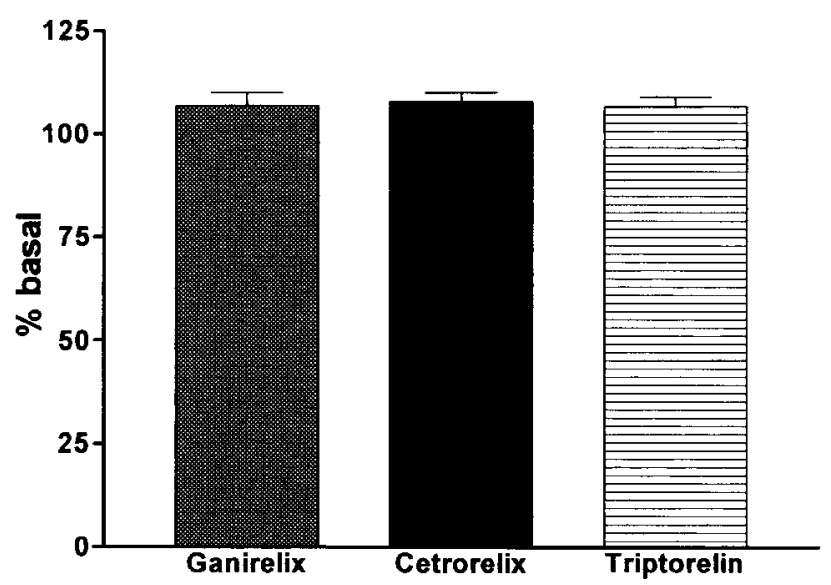

Figure 4 Granulosa-lutein cells were treated in vitro for $48 \mathrm{~h}$ with cetrorelix, ganirelix or triptorelin, $1 \mathrm{nmol} / \mathrm{l}$ each. IGFBP-2 was measured by RIA. Untreated controls were set to $100 \%$. IGFBP-2 values of different patients were in the range $10.2-38.9 \mathrm{ng} / \mathrm{ml}$. $5-10$ replicates were performed per group. Values are expressed as means \pm S.E.M.

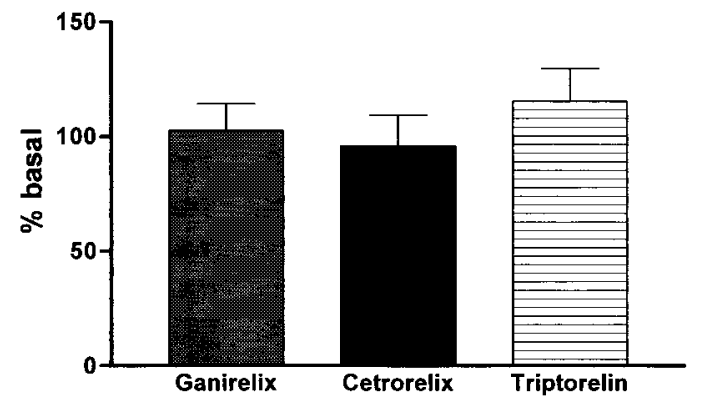

Figure 5 Granulosa-lutein cells were treated in vitro for $48 \mathrm{~h}$ with cetrorelix, ganirelix or triptorelin, $1 \mathrm{nmol} / \mathrm{l}$ each. PAPP-A was measured by enzyme immunoassay. Untreated controls were set to $100 \%$. PAPP-A values of different patients were in the range $0.2-0.4 \mathrm{mIU} / \mathrm{ml}$. 5-10 replicates were performed per group. Values are expressed as means \pm S.E.M.

protease of IGFBP-4. This is in agreement with recent studies showing high levels of PAPP-A and consequently no detected IGFBP-4 in dominant follicles or granulosa-lutein cells $(30,32)$.

Triptorelin, ganirelix and cetrorelix did not affect PAPP-A release of granulosa-lutein cells. No differences between treatment groups could be observed (Fig. 5).

\section{Discussion}

In the present study we investigated the effects of GnRH analogues on IGF-II, IGFBP-2 and PAPP-A, the most important factors of the human ovarian IGF system, in human granulosa-lutein cells. The specific aim was to identify the actions of the two new GnRHants cetrorelix and ganirelix, which have both been approved for $\mathrm{COH}$ in some countries. Cetrorelix, ganirelix and triptorelin did not exert any effects on IGF-II, IGFBP-2 and PAPP-A.

The requirement for effects of pharmacological doses of GnRH analogues on the function of the human ovary is the presence of active and functional GnRH receptors. Emerging evidence exists for their expression in the human ovary. Binding studies with human luteal tissue or cells have revealed no, or low- or high-affinity binding sites for GnRH (34). High-affinity GnRH receptors have also been detected by quantitative autoradiography in human granulosa cells at a late stage of follicular maturation (35). Brus et al. (11) have demonstrated GnRH receptors in a large proportion of follicular aspirates containing granulosa-lutein cells but not in preovulatory follicles, suggesting that $\mathrm{GnRH}$ receptors are present in human ovarian tissue predominantly after the luteinizing hormone surge. The expression of GnRH receptor gene in the human ovary has been shown by several groups $(8-10,13$, 36). GnRH receptor gene expression is upregulated by GnRH, but downregulated by hCG (10). The presence of GnRH receptors in human granulosa-lutein cells points to the possibility that they mediate actions of 
GnRH. However, concentrations of hypothalamic GnRH in the peripheral circulation are presumably much too low to activate extrapituitary GnRH receptors. In contrast, the application of GnRH analogs to patients in protocols of $\mathrm{COH}$ results in serum concentrations which might be sufficient to interact with these receptors (37). The GnRH analog concentration of $1 \mathrm{nmol} / \mathrm{l}$ we used for all in vitro experiments should be sufficient to detect any differences, since compared with our recently published pharmacokinetic data on cetrorelix the levels in plasma and follicular fluid were lower (32).

The actions of GnRHants in the human ovary are not understood. Minaretzis et al. (12) reported that treatment of patients undergoing $\mathrm{COH}$ with the GnRHant Nal-Glu has no effect on the progesterone production of granulosa-lutein cells obtained from these patients. Aromatase activity, however, was reduced in the GnRHant group during the first $6 \mathrm{~h}$ of culture. Two studies suggested that the luteal function in GnRHant-treated patients may be less impaired compared with GnRHags $(38,39)$. They compared cetrorelix with GnRHag buserelin and found that cells from patients treated with cetrorelix respond earlier to in vitro hormone stimulation. Our previous studies, however, did not find any ovarian effects of GnRHants. Neither did they influence cAMP production (14), nor steroidogenesis in human granulosa-lutein cells (13).

Given the fact that granulosa-lutein cells express GnRH receptors they do not necessarily mediate GnRH or GnRHants actions. For example in ovarian and endometrial carcinoma cells, activation of GnRH receptors leads to antiproliferative effects of GnRHags and GnRHants (40). Also, in these cells GnRH receptor activation does not lead to hydrolysis of phosphoinositides by phospholipase $\mathrm{C}$, as in pituitary gonadotropes, but inhibits mitogenic activity and signaling of epidermal growth factor (41). Therefore the lack of GnRHants effects on steroidogenesis and cAMP production in human ovary does not exclude any ovarian actions of these compounds in general.

The lower pregnancy rates in GnRHant-treated patients remain a hurdle to a wide acceptance of these compounds. The contributing factors are still a matter of debate. Some blame lower estradiol levels before oocyte pick-up (42), others discuss an impaired endometrial receptiveness caused by GnRHants (25). The proper function of the ovarian IGF system is another prerequisite for normal follicular development and finally implantation (25).

The IGF family is composed of IGF-I and IGF-II peptides, six structurally homologous high-affinity IGFBPs (IGFBP-1 to -6), IGF-specific proteases and two types of IGF receptors. IGF-I and IGF-II are small, mitogenic and antiapoptotic peptides that promote differentiation and also have insulin-like metabolic effects mediated upon binding to specific membrane receptors (28, $43,44)$.
In the human ovary, the granulosa cell is a site of IGF-II rather than IGF-I gene expression $(26,27,45)$. IGF-I mRNA is hardly detectable in the human ovary and in granulosa cells at no time of follicle maturation, whereas IGF-II synthesis has been found in granulosa-lutein cells and in preovulatory granulosa cells $(26,46)$. IGF-II stimulates, as the primary IGF in the human ovary, steroidogenesis along with FSH in granulosa cells. At the time of follicle selection, in the estrogen-dominant follicle, granulosa IGF-II synthesis increases dramatically (28). In human ovaries IGFBP-2 and -4 are known to inhibit the action of IGF-II, which they predominantly bind. IGFBP-2 and -4 can be localized in granulosa and theca cells of atretic follicles, but are negligible in primordial, preantral and antral follicles (29). The follicular fluid of atretic/androgen-dominant follicles contains high levels of IGFBP-2 and -4, subsequently low levels and activity of IGF-II (47-49). In contrast an increase of lower molecular mass forms of IGFBP-2 and -4 in dominant follicles suggests an increased activity of proteases of IGFBPs (50), resulting in a decreased affinity of IGFBP-2 and -4 for IGF-II. Moreover, protease activity is also observed in follicular fluid of developing but not atretic follicles $(51,52)$.

The effects of IGF-II are inhibited by IGFBP- 4 and are enhanced by cleavage of IGFBP-4 through a specific protease decreasing its affinity for IGFs. The protease of IGFBP-4 was found to be PAPP-A (32). PAPP-A is present in follicular fluids of estrogen-dominant follicles and luteinized granulosa cells, but could not be detected in androgen-dominant follicles $(30,51,53)$. Consequently highest activity of IGF-II and low levels of IGFBP-4 in estrogen-dominant follicles and luteinized granulosa cells were noted. These observations are in agreement with our failure to detect IGFBP-4 in human granulosa-lutein cells. In contrast, the levels of PAPP-A, degrading IGFBP-4, were consistently high, which is in accord with previous data as well (54).

This is substantial evidence that IGFs and IGFBPs are involved in folliculogenesis and steroidogenesis in the ovary and therefore an imbalance of the intraovarian IGF system due to the application of GnRHants would disturb the physiological differentiation of the follicle growth and maturation, but also of the endometrium and the implantation of the embryo.

In conclusion, we have shown for the first time that the GnRHants cetrorelix and ganirelix do not affect the IGF system of human granulosa-lutein cells. It is therefore unlikely that the slightly diminished pregnancy rates in GnRHants cycles are due to ovarian effects of GnRHants.

\section{Acknowledgements}

Ganirelix was provided by Professor Coelingh-Bennink (N.V. Organon, Oss, The Netherlands). Cetrorelix was donated by PD Dr Reissmann (ASTA Medica, Frankfurt, Germany). 


\section{References}

1 Huirne JA \& Lambalk CB. Gonadotropin-releasing-hormonereceptor antagonists. Lancet 2001358 1793-1803.

2 Clayton RN, Harwood JP \& Catt KJ. Gonadotropin-releasing hormone analogue binds to luteal cells and inhibits progesterone production. Nature 1979282 90-92.

3 Hsueh AJ \& Jones PB. Extrapituitary actions of gonadotropinreleasing hormone. Endocrine Reviews 19812 437-461.

4 Bauer-Dantoin AC \& Jameson JL. Gonadotropin-releasing hormone receptor messenger ribonucleic acid expression in the ovary during the rat estrous cycle. Endocrinology 1995136 $4432-4438$

5 Bramley TA, McPhie CA \& Menzies GS. Human placental gonadotrophin-releasing hormone $(\mathrm{GnRH})$ binding sites: I Characterization, properties and ligand specificity. Placenta 1992 13 555-581.

6 Chegini N, Rong H, Dou Q, Kipersztok S \& Williams RS. Gonadotropin-releasing hormone (GnRH) and GnRH receptor gene expression in human myometrium and leiomyomata and the direct action of $\mathrm{GnRH}$ analogs on myometrial smooth muscle cells and interaction with ovarian steroids in vitro. Journal of Clinical Endocrinology and Metabolism 199681 3215-3221.

7 Stojilkovic SS \& Catt KJ. Expression and signal transduction pathways of gonadotropin-releasing hormone receptors. Recent Progress in Hormone Research 199550 161-205.

8 Kakar SS, Musgrove LC, Devor DC, Sellers JC \& Neill JD. Cloning, sequencing, and expression of human gonadotropin releasing hormone $(\mathrm{GnRH})$ receptor. Biochemical and Biophysical Research Communications 1992189 289-295.

9 Minaretzis D, Jakubowski M, Mortola JF \& Pavlou SN. Gonadotropin-releasing hormone receptor gene expression in human ovary and granulosa-lutein cells. Journal of Clinical Endocrinology and Metabolism 199580 430-434.

10 Peng C, Fan NC, Ligier M, Vaananen J \& Leung PC. Expression and regulation of gonadotropin-releasing hormone $(\mathrm{GnRH})$ and GnRH receptor messenger ribonucleic acids in human granulosa-luteal cells. Endocrinology 1994135 1740-1746.

11 Brus L, Lambalk CB, de Koning J, Helder MN, Janssens RM \& Schoemaker J. Specific gonadotrophin-releasing hormone analogue binding predominantly in human luteinized follicular aspirates and not in human pre-ovulatory follicles. Human Reproduction 199712 769-773.

12 Minaretzis D, Alper MM, Oskowitz SP, Lobel SM, Mortola JF \& Pavlou SN. Gonadotropin-releasing hormone antagonist versus agonist administration in women undergoing controlled ovarian hyperstimulation: cycle performance and in vitro steroidogenesis of granulosa-lutein cells. American Journal of Obstetrics and Gynecology 1995172 1518-1525.

13 Weiss JM, Oltmanns K, Gürke EM, Polack S, Eick F, Felberbaum R et al. Actions of gonadotropin-releasing hormone antagonists on steroidogenesis in human granulosa lutein cells. European Journal of Endocrinology $2001 \mathbf{1 4 4} 677-685$.

14 Demirel LC, Weiss JM, Polack S, Unlu C, Diedrich K \& Ortmann O. Effect of the gonadotropin-releasing hormone antagonist ganirelix on cyclic adenosine monophosphate accumulation of human granulosa-lutein cells. Fertility and Sterility $2000 \mathbf{7 4} 1001-1007$.

15 Albano C, Smitz J, Camus M, Riethmuller-Winzen H, Van Steirteghem A \& Devroey P. Comparison of different doses of gonadotropin-releasing hormone antagonist Cetrorelix during controlled ovarian hyperstimulation. Fertility and Sterility 1997 67 917-922.

16 Diedrich K, Diedrich C, Santos E, Zoll C, Al Hasani S, Reissmann T et al. Suppression of the endogenous luteinizing hormone surge by the gonadotrophin-releasing hormone antagonist Cetrorelix during ovarian stimulation. Human Reproduction 19949 $788-791$.

17 Felberbaum R, Reissmann T, Küpker W, Al Hasani S, Bauer O, Schill $\mathrm{T}$ et al. Hormone profiles under ovarian stimulation with human menopausal gonadotropin (hMG) and concomitant administration of the gonadotropin releasing hormone (GnRH)antagonist Cetrorelix at different dosages. Journal of Assisted Reproduction and Genetics 199613 216-222.

18 Felberbaum RE, Reissmann T, Küpker W, Bauer O, Al Hasani S, Diedrich $\mathrm{C}$ et al. Preserved pituitary response under ovarian stimulation with HMG and GnRH antagonists (Cetrorelix) in women with tubal infertility. European Journal of Obstetrics, Gynecology and Reproductive Biology 199561 151-155.

19 Hughes EG, Fedorkow DM, Daya S, Sagle MA, Van de KP \& Collins JA. The routine use of gonadotropin-releasing hormone agonists prior to in vitro fertilization and gamete intrafallopian transfer: a meta-analysis of randomized controlled trials. Fertility and Sterility $1992 \mathbf{5 8} 888-896$.

20 Weiss JM, Felberbaum RE, Montzka P, Ludwig M, Strik D, Bals-Pratsch $\mathrm{M}$ et al. Controlled ovarian hyperstimulation $(\mathrm{COH})$ with recombinant FSH and concomitant midcyclic GnRH antagonist treatment (Ganirelix) at different dosages. Geburtshilfe und Frauenheilkunde 199959 209-214.

21 Olivennes F, Belaisch-Allart J, Emperaire JC, Dechaud H, Alvarez S, Moreau L et al. Prospective, randomized, controlled study of in vitro fertilization - embryo transfer with a single dose of a luteinizing hormone-releasing hormone (LH-RH) antagonist (cetrorelix) or a depot formula of an LH-RH agonist (triptorelin). Fertility and Sterility 200073 314-320.

22 Albano C, Felberbaum RE, Smitz J, Riethmuller-Winzen H, Engel J, Diedrich K et al. Ovarian stimulation with HMG: results of a prospective randomized phase III European study comparing the luteinizing hormone-releasing hormone (LHRH)-antagonist cetrorelix and the LHRH-agonist buserelin. European Cetrorelix Study Group. Human Reproduction 200015 526-531.

23 Borm G \& Mannaerts B. Treatment with the gonadotrophinreleasing hormone antagonist ganirelix in women undergoing ovarian stimulation with recombinant follicle stimulating hormone is effective, safe and convenient: results of a controlled, randomized, multicentre trial. The European Orgalutran Study Group. Human Reproduction 200015 1490-1498.

24 Ludwig M, Katalinic A \& Diedrich K. Use of GnRH antagonists in ovarian stimulation for assisted reproductive technologies compared to the long protocol. Meta-analysis. Archives of Gynecology and Obstetrics 2001265 175-182.

25 Hernandez ER. Embryo implantation and GnRH antagonists: embryo implantation: the Rubicon for GnRH antagonists. Human Reproduction 200015 1211-1216.

26 el Roeiy A, Chen X, Roberts VJ. LeRoith D, Roberts CT Jr \& Yen SS. Expression of insulin-like growth factor-I (IGF-I) and IGF-II and the IGF-I, IGF-II, and insulin receptor genes and localization of the gene products in the human ovary. Journal of Clinical Endocrinology and Metabolism 199377 1411-1418.

27 Hernandez ER, Hurwitz A, Vera A, Pellicer A, Adashi EY, LeRoith D et al. Expression of the genes encoding the insulin-like growth factors and their receptors in the human ovary. Journal of Clinical Endocrinology and Metabolism 1992 74 419-425.

28 Giudice LC. Insulin-like growth factor family in Graafian follicle development and function. Journal of the Society for Gynecologic Investigation 20018 S26-S29.

29 Peng X, Maruo T, Samoto T \& Mochizuki M. Comparison of immunocytologic localization of insulin-like growth factor binding protein- 4 in normal and polycystic ovary syndrome human ovaries. Endocrine Journal 199643 269-278.

30 Conover CA, Faessen GF, Ilg KE, Chandrasekher YA, Christiansen $\mathrm{M}$, Overgaard MT et al. Pregnancy-associated plasma protein-A is the insulin-like growth factor binding protein-4 protease secreted by human ovarian granulosa cells and is a marker of dominant follicle selection and the corpus luteum. Endocrinology 2001 $1422155-2158$.

31 Ludwig M, Albano C, Olivennes F, Felberbaum RE, Smitz J, Ortmann $\mathrm{O}$ et al. Plasma and follicular fluid concentrations of LHRH antagonist cetrorelix (Cetrotide) in controlled ovarian stimulation for IVF. Archives of Gynecology and Obstetrics 2002 $26612-17$. 
32 Conover CA, Oxvig C, Overgaard MT, Christiansen M \& Giudice LC. Evidence that the insulin-like growth factor binding protein-4 protease in human ovarian follicular fluid is pregnancy associated plasma protein-A. Journal of Clinical Endocrinology and Metabolism $1999844742-4745$.

33 Ramasharma K \& Li CH. Human pituitary and placental hormones control human insulin-like growth factor II secretion in human granulosa cells. PNAS $1987842643-2647$.

34 Clayton RN \& Huhtaniemi IT. Absence of gonadotropin-releasing hormone receptors in human gonadal tissue. Nature 1982299 56-59.

35 Latouche J, Crumeyrolle-Arias M, Jordan D, Kopp N, AugendreFerrante B, Cedard L et al. GnRH receptors in human granulosa cells: anatomical localization and characterization by autoradiographic study. Endocrinology 1989125 1739-1741.

36 Fraser HM, Sellar RE, Illingworth PJ \& Eidne KA. GnRH receptor mRNA expression by in-situ hybridization in the primate pituitary and ovary. Molecular Human Reproduction 19962 117-121.

37 Ortmann O, Weiss JM \& Diedrich K. Embryo implantation and GnRH antagonists: ovarian actions of GnRH antagonists. Human Reproduction 200116 608-611.

38 Lin LS, Roberts VJ \& Yen SS. Expression of human gonadotropinreleasing hormone receptor gene in the placenta and its functional relationship to human chorionic gonadotropin secretion. Journal of Clinical Endocrinology and Metabolism 1995 80 580-585.

39 Lin Y, Kahn JA \& Hillensjo T. Is there a difference in the function of granulosa-luteal cells in patients undergoing in-vitro fertilization either with gonadotrophin-releasing hormone agonist or gonadotrophin-releasing hormone antagonist? Human Reproduction $1999 \mathbf{1 4} 885-888$.

40 Emons G, Ortmann O, Schulz KD \& Schally A. Growth-inhibitory actions of analogues of luteinizing hormone releasing hormone on tumor cells. Trends in Endocrinology and Metabolism $1997 \mathbf{8}$ 355-362.

41 Emons G, Muller V, Ortmann O \& Schulz KD. Effects of LHRHanalogues on mitogenic signal transduction in cancer cells. Journal of Steroid Biochemistry and Molecular Biology $1998 \mathbf{6 5}$ 199-206.

42 Gordon K. Gonadotropin-releasing hormone antagonists implications for oocyte quality and uterine receptivity. Annals of the New York Academy of Sciences $200194349-54$.

43 Adashi EY, Resnick CE, Hurwitz A, Ricciarellie E, Hernandez ER, Roberts CT et al. The intra-ovarian IGF system. Growth Regulation $1992210-15$.

44 Giudice LC. Insulin-like growth factors and ovarian follicular development. Endocrine Reviews 199213 641-669.

45 Mason HD, Willis DS, Holly JM \& Franks S. Insulin preincubation enhances insulin-like growth factor-II (IGF-II) action on steroidogenesis in human granulosa cells. Journal of Clinical Endocrinology and Metabolism 199478 1265-1267.

46 el Roeiy A, Chen X, Roberts VJ, Shimasakai S, Ling N, LeRoith D et al. Expression of the genes encoding the insulin-like growth factors (IGF-I and II), the IGF and insulin receptors, and IGF-binding proteins-1-6 and the localization of their gene products in normal and polycystic ovary syndrome ovaries. Journal of Clinical Endocrinology and Metabolism 199478 1488-1496.

47 Cataldo NA, Woodruff TK \& Giudice LC. Regulation of insulin-like growth factor binding protein production by human luteinizing granulosa cells cultured in defined medium. Journal of Clinical Endocrinology and Metabolism 199376 207-215.

48 Giudice LC, Van Dessel HJ, Cataldo NA, Chandrasekher YA, Yap OW \& Fauser BC. Circulating and ovarian IGF binding proteins: potential roles in normo-ovulatory cycles and in polycystic ovarian syndrome. Progress in Growth Factor Research $19956397-408$.

49 San Roman GA \& Magoffin DA. Insulin-like growth factor-binding proteins in healthy and atretic follicles during natural menstrual cycles. Journal of Clinical Endocrinology and Metabolism 199376 625-632.

50 Cwyfan HS, Mason HD, Franks S \& Holly JM. Modulation of the insulin-like growth factor-binding proteins by follicle size in the human ovary. Journal of Endocrinology 1997154 35-43.

51 Chandrasekher YA, Van Dessel HJ, Fauser BC \& Giudice LC. Estrogen- but not androgen-dominant human ovarian follicular fluid contains an insulin-like growth factor binding protein-4 protease. Journal of Clinical Endocrinology and Metabolism 1995 $802734-2739$.

52 Iwashita M, Kudo Y, Yoshimura Y, Adachi T, Katayama E \& Takeda Y. Physiological role of insulin-like-growth-factor-binding protein-4 in human folliculogenesis. Hormone Research $1996 \mathbf{4 6}$ (Suppl 1) 31-36.

53 Hourvitz A, Widger AE, Filho FL, Chang RJ, Adashi EY \& Erickson GF. Pregnancy-associated plasma protein-A gene expression in human ovaries is restricted to healthy follicles and corpora lutea. Journal of Clinical Endocrinology and Metabolism $2000 \mathbf{8 5}$ 4916-4920.

54 Chegini N, Lei ZM, Rao CV \& Bischof P. The presence of pregnancy-associated plasma protein-A in human corpora lutea: cellular and subcellular distribution and dependence on reproductive state. Biology of Reproduction 199144 201-206.

Received 14 February 2003

Accepted 2 May 2003 